\title{
STUDY OF THE MICROSTRUCTURES AND MECHANICAL PROPERTIES OF ALUMINIUM HYBRID COMPOSITES WITH $\mathrm{SiC}$ AND $\mathrm{Al}_{2} \mathrm{O}_{3}$
}

\author{
ŠTUDIJA MIKROSTRUKTUR IN MEHANSKIH LASTNOSTI \\ ALUMINIJEVIH HIBRIDNIH KOMPOZITOV S SiC IN $\mathrm{Al}_{2} \mathrm{O}_{3}$
}

Palanisamy Pugalenthi ${ }^{1}$, Murugesan Jayaraman², Venkatajalapathy Subburam ${ }^{1}$

1Paavai Engineering College, Department of Mechanical Engineering, NH-44, Pachal, Namakkal District, Pincode: 637018, Tamilnadu, India ${ }^{2}$ Velalar College of Engineering and Technology, Department of Mechanical Engineering, Thindal, Erode District, Pincode: 638012, Tamilnadu, India

Prejem rokopisa - received: 2018-06-08; sprejem za objavo - accepted for publication: 2018-09-13

Aluminium metal-matrix composites are widely produced with different ceramic compounds as reinforcements to enhance their properties and to suit various structural applications. The present work involves the fabrication of Al7075 composites with silicon carbide $(\mathrm{SiC})$ and aluminum oxide $\left(\mathrm{Al}_{2} \mathrm{O}_{3}\right)$ as reinforcements through stir casting. Four specimens were produced with different compositions comprising $\mathrm{SiC}(3,5,7$ and $9 w / \%)$ and $\mathrm{Al}_{2} \mathrm{O}_{3} 2 w / \%$ in all the combinations. Mechanical properties like ultimate tensile strength (UTS), yield strength (YS), percentage of elongation (\% of elongation) and hardness (VHN) were examined, along with fractography studies. The microstructural characterization of the composites was also studied through micrographs obtained from the scanning electron microscope (SEM). The test results revealed that the increase in the $w / \%$ fractions of the reinforcement materials caused an increase in the tensile strength, yield strength and hardness of the aluminium composite, except for the \% of elongation, which is reduced with the addition of ceramic particles.

Keywords: stir-casting method, hybrid composites, mechanical properties and microstructure

Kompoziti s kovinsko osnovo iz aluminija se pogosto izdelujejo z različnimi keramičnimi spojinami kot ojačitveno fazo, in s tem postanejo uporabni za izdelavo različnih strukturnih aplikacij. V pričujoči raziskavi so avtorji izdelali kompozite na osnovi Al zlitine $7075 \mathrm{z}$ dodatkom delcev silicijevega karbida $(\mathrm{SiC})$ in aluminijevega oksida $\left(\mathrm{Al}_{2} \mathrm{O}_{3}\right)$ kot ojačitveno fazo med premešavanjem taline. Izdelali so štiri vzorce $\mathrm{z}$ različno vsebnostjo $\mathrm{SiC}(3,5,7$ in $9 w / \%)$ in $\mathrm{v}$ vseh primerih še $\mathrm{z}$ dodatkom $2 \mathrm{w} / \% \mathrm{Al}_{2} \mathrm{O}_{3}$. Določili so mehanske lastnosti izdelanih kompozitov - natezno trdnost pri pretrgu (UTS), mejo plastičnosti (YS), raztezek (\%) in trdoto (VHN). Nato so izvedli še analize prelomov (fraktografijo) nateznih preizkušancev s pomočjo vrstičnega elektronskega mikroskopa (SEM). Rezultati preiskav so pokazali, da povečanje dodatka ojačitvene faze v obliki keramičnih delcev povzroči zvišanje natezne trdnosti, meje plastičnosti in trdote, zmanjša pa se raztezek.

Ključne besede: metoda litja s premešavanjem, hibridni kompoziti, mehanske lastnosti in mikrostruktura

\section{INTRODUCTION}

Composite materials combine the desirable properties of the constituent materials and provide enhanced physical and mechanical properties. Composite materials find applications in almost all industries today. The automobile and aerospace industries are constantly in search of composites that possess higher strength and are lighter in weight for structural applications. Aluminium is preferred as a structural material in these areas because of its light weight. Ceramic particulates are added to the aluminium base matrix as a reinforcement to fabricate aluminium metal-matrix composites (AMMCs), which provide improved strength. Among the aluminium alloy series, the aluminium 7075 alloy has many favorable properties, like higher strength, good wear resistance, higher toughness and stiffness. The ceramic reinforcements added to the aluminium matrix also give further improvement to the endurance at higher operating tem-

*Corresponding author e-mail

mecpugal@yahoo.com peratures. Most industries prefer metal-matrix composites with aluminium to take advantage of its ease of fabrication. Though many casting methods are available, stir casting is considered for manufacturing AMMCs as the technique is simple, economical and because of its capability for large volume production.

The tensile strength and fatigue strengths of a SiC-whisker-reinforced AA7075 specimen produced by the powder metallurgy method was tested by Komai et al. ${ }^{1}$ in normal atmospheric and water environments. It was observed in the report that all the mechanical properties showed enhanced values, except the elongation to failure. The pattern of propagation of a crack for fatigue failure was also studied. The water environment was found to give a shorter fatigue life due to the effect of corrosion. Azim et al. ${ }^{2}$ produced a MMC with A12024 base material and $\mathrm{Al}_{2} \mathrm{O}_{3}$ as the ceramic reinforcement to study the change in the mechanical peoperties. The observtions revealed that the increments in the volume percentage of $\mathrm{Al}_{2} \mathrm{O}_{3}$ caused an increase in the ultimate tensile strength and a decrease in the ductility. 
Lee et al. ${ }^{3}$ produced $\mathrm{SiC}_{\mathrm{p}}$-reinforced $\mathrm{AA} 7075$ and a control AA7075 (without $\mathrm{SiC}_{\mathrm{p}}$ ) using a pressurelessinfiltration technique in a nitrogen atmosphere. From the test results it was observed that even the control-AA7075 specimen (without $\mathrm{SiC}_{\mathrm{p}}$ ) showed enhanced strength due to the formation of AlN particles and the SiC-reinforced specimens revealed still higher values of strength for all the age-hardening conditions. The powder-metallurgy route with a centrifugal atomization technique was used by Hong et al. ${ }^{4}$ to fabricate a MMC comprising AA $2024+$ SiC. The analysis involved a study of the influnce of clustering on the mechanical properties. The test results showed that the inclusion of $\mathrm{SiC}$ improved the yield strength and the ultimate strength, while it decreased the fracture strength.

Kalkanli et al. ${ }^{5}$ produced AMMCs by incorporating $\mathrm{SiC}$ particles of around 29 microns into the AA7075 matrix using the vertical pressure-casting technique. Four test specimens containing $\mathrm{SiC}$ particles of $(10,15$, 20 and 30$) w / \%$ fractions were fabricated and subjected to tensile and bend tests in the as-cast condition and also after heat treatment. The specimen with $10 \% \mathrm{SiC}_{\mathrm{p}}$ was found to give the maximum flexural strength in both the as-cast condition (450 MPa) and the heat-treated condition (588 MPa), gaining a $10 \%$ and $44 \%$ increment, respectively, from the base-alloy value. The hardness values were also observed to increase considerably for both the as-cast and heat-treated specimens with the weight percentage of $\mathrm{SiC}$ particles. Sajjadi et al. ${ }^{6}$ fabricated an $\mathrm{Al}(\mathrm{A} 356) / \mathrm{Al}_{2} \mathrm{O}_{3 \mathrm{P}}$ composite through stir casting to study the mechanical properties. The observations suggest that an increase in the ultimate strength and yield strength could be achieved by increasing the $w / \%$ of $\mathrm{Al}_{2} \mathrm{O}_{3}$ and also by reducing the size of the $\mathrm{Al}_{2} \mathrm{O}_{3}$ particles.

Aluminium was reinforced with $\mathrm{SiC}$ and $\mathrm{Al}_{2} \mathrm{O}_{3}$ (alumina) using different $w / \%$ to experimentally analyse the behaviour change in the resulting composite by Daljeetsingh et al. ${ }^{7}$ It was found that an increase in the $w / \%$ of the reinforcements caused an increment in the mechanical properties, like hardness, yield strength and ultimate strength. The influnce of ceramic materials changes the ductile behaviour of the material to brittle, as a result of which the elongation decreases. A mathematical model was devolped by Indumathi et al. ${ }^{8}$ to predict the tensile strength and the percentage elongation of the as-cast composites $\left(\mathrm{A} 17075+\mathrm{Al}_{2} \mathrm{O}_{3}\right)$ through a design of experiments by taking the size and percentage fraction of alumina as the parameters. The observations showed that the UTS of the composite increased by $20 \%$ and the percentage elongation reduced by approximately $30 \%$ compared to the matrix material.

Uvaraja et al. ${ }^{9}$ investigated hybrid MMCs using the Taguchi technique to obtain optimum input levels for dry-sliding wear conditions. From the experimental results it was observed that the samples containing $10 \mathrm{w} / \%$ of silicon carbide and $3 w / \%$ of boron carbide have a high hardness and a good toughness. Furthermore, it was recommended that this composite with optimum $w / \%$ could be utilised for applications in the heavy-vehicle sector. Valve-seat inserts were produced from AA7075 and $\mathrm{AA} 7075+\mathrm{SiC}_{\mathrm{p}}$ composites containing $(10,15,20$ and 25) \% reinforcements for a comparative study by Bhusan et al. ${ }^{10}$ It was observed in the course of the study that when the reinforcements exceed $25 \% \mathrm{SiC}_{\mathrm{p}}$ deficiencies like non-uniformity in the distribution of particles, a poor surface finish and high tool wear arise. These properties became enhanced in the range 10-15 w/\% inclusion of $\mathrm{SiC}_{\mathrm{p}}$.

Metal-matrix composites of AA7075-TiC with $4 \%$ and $8 \%$ of TiC were fabricated using the in-situ casting method by Baskaran et al. ${ }^{11}$ to conduct dry-sliding wear tests. Taguchi's L27 orthogonal array design was used to study the influence of reinforcement quantity, applied load, sliding velocity and sliding distance on the wear rate. The experimental results revealed that the applied load and the sliding velocity were the dominant input parameters. The optimal combination for achieving the minimum wear rate was observed as $4 w / \%$ of TiC (reinforcement), $9.81 \mathrm{~N}$ (applied load), $3 \mathrm{~m} / \mathrm{s}$ (sliding velocity) and $1500 \mathrm{~m}$ (sliding distance). Wu et al. ${ }^{12}$ used a sintering technique to reinforce $\mathrm{B}_{4} \mathrm{C}(7.5 \mathrm{w} / \%)$ into the Al7075 alloy and studied the densification behaviour of the composite. It was reported that full densification, good inter-particle bonding and significant improvement in the mechanical properties were achieved at $530{ }^{\circ} \mathrm{C}$ and 3 min of holding time in a plasma-activated sintering method.

Vignesh et al. ${ }^{13}$ focussed on the behaviour of an Al7075- $\mathrm{Al}_{2} \mathrm{O}_{3}$ metal-matrix composite in an industrial environment and sea water to study the occurance of corrosion and a change in the surface morphology. From the SEM images it was observed that intergranular corrosion occurred in the industrial environment and sea water produced pitting corrosion. Rajeswari et al. ${ }^{14}$ attempted to identify the effect of the input parameters on the quality of the casting produced (to obtain a defect-free casting) and mechanical properties like tensile strength and hardness. The ANOVA results showed that the w/\% of $\mathrm{SiC}$ and $\mathrm{Al}_{2} \mathrm{O}_{3}$ were the most influential factors, followed by the stirring speed. It was further reported that homogenous mixing was ensured at high temperatures due to the improved wettability of the reinforcements.

Tanwir alam et al. ${ }^{15}$ produced nanocomposites using a stir-casting process by reinforcing silicon carbide nanoparticles (mechanically milled) into an aluminium alloy metal matrix. The nanosize of the particles ensured improved wettability and also better embedding of the reinforcement particles into the alloy matrix. The research results showed improvements of $125 \%$ in hardness, $41 \%$ in yield strength, $45 \%$ in ultimate tensile strength and also an improvement of the compressive strength from $311 \mathrm{MPa}$ to $603 \mathrm{MPa}$ (at $5 \%$ inclusion of 
$\mathrm{SiC})$. The fracture study revealed that the debonding and cracking of the particles were the main causes of fracture. Ashok et al. ${ }^{16}$ utilised stir casting to fabricate $\mathrm{A} 18011+\mathrm{SiC}$ composites with a uniform distribution of $\mathrm{SiC}_{\mathrm{p}}$ in the aluminium alloy matrix. The size effect on the hardness revealed that the increase in hardness is caused by a decrease in the particle size of the silicon carbide. The yield strength and the tensile strength were reduced for composites containing coarse particles of silicon carbide. The composite containing $6 w / \%$ SiC and a particle size of 63 microns gave the highest yield strength $(87 \mathrm{MPa})$ and tensile strength $(111 \mathrm{MPa})$.

Sambathkumar et al. ${ }^{17}$ fabricated an A17075+SiC+ TiC composite to investigate the mechanical and corrosion characteristics. An increase in the reinforcements up to $15 \%$ by volume increased the microhardness. The composition containing $10 \%$ by volume of both $\mathrm{SiC}_{\mathrm{p}}$ and $\mathrm{TiC}_{\mathrm{p}}$ gave a tensile strength of $240 \mathrm{MPa}$, which is an improvement of $33 \%$ from the base alloy's tensile strength. Mavhungu et al. ${ }^{18}$ reviewed the advancements in the manufacturing and processing methods of AMMCs. The favourable properties of these composites, like high specific stiffness and strength-to-weight ratio, were discussed for applications in the automotive industry.

Kannan et al. ${ }^{19}$ compared the mechanical properties and microstructural characteristics of aluminium nanocomposites with single and hybrid-type reinforcements. The stir-casting method was used to fabricate three samples of single-reinforced nanocomposites in which the reinforcements were included after preheating them to $400{ }^{\circ} \mathrm{C}, 500{ }^{\circ} \mathrm{C}$, and $600{ }^{\circ} \mathrm{C}$, respectively. Two hybrid nanocomposites were also produced in this way, preheating the reinforcements to $500{ }^{\circ} \mathrm{C}$ before inclusion. The results showed that when the $w / \%$ of nano-reinforcement did not exceed the $2 \%$ level, the preheat temperature of $500{ }^{\circ} \mathrm{C}$ prevented agglomeration and helped the uniform distribution of ceramic particles in the aluminium matrix.

The present work includes the fabrication of $\mathrm{AMMCs}$ with $\mathrm{Al} 7075$ as the matrix and $\mathrm{SiC}+\mathrm{Al}_{2} \mathrm{O}_{3}$ particles at different $\mathrm{w} / \%$ fractions as the reinforcements using a stir-casting method. The mechanical and metallurgical characteristics of the samples are studied using mechanical tests and SEM micrographs.

\section{MATERIALS AND METHODS}

\subsection{Experimental part}

\subsubsection{Fabrication of composite}

The composite specimens were produced using Al7075 rods that were melted to serve as the matrix for the ceramic particles of $\mathrm{SiC}$ and $\mathrm{Al}_{2} \mathrm{O}_{3}$ (30/40 micron size) that mix with the bulk of the aluminium alloy as reinforcements in the stir-casting method. The chemical composition of the A17075, comprising various elements by weight percentage, is shown in Table $\mathbf{1}$.

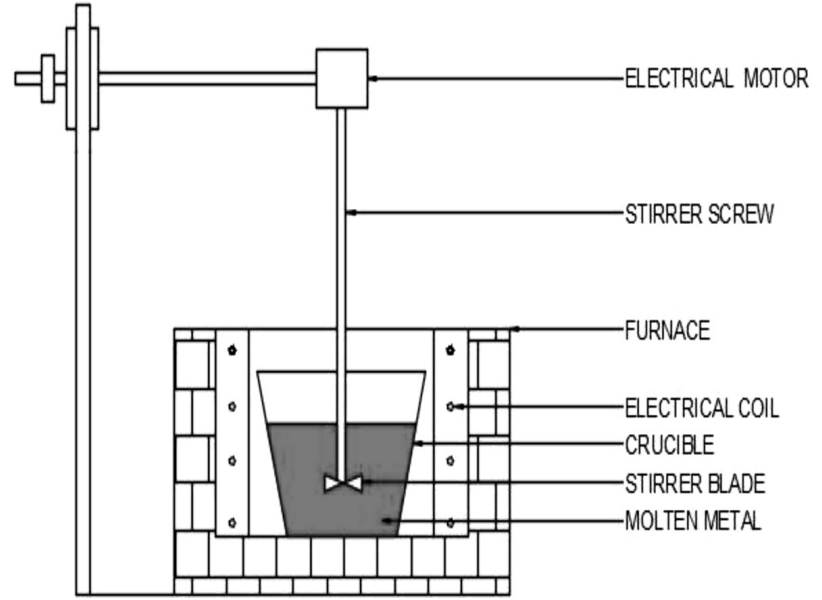

Figure 1: Schematic diagram of the stir-casting setup

Table 1: Chemical compositions of A17075

\begin{tabular}{|c|c|c|c|c|c|c|c|c|c|}
\hline $\begin{array}{c}\text { Mater } \\
\text { ial }\end{array}$ & $\mathrm{Zn}$ & $\mathrm{Mg}$ & $\mathrm{Cu}$ & $\mathrm{Si}$ & $\mathrm{Mn}$ & $\mathrm{Fe}$ & $\mathrm{Cr}$ & $\mathrm{Ti}$ & $\mathrm{Al}$ \\
\hline $\begin{array}{c}\text { Weig } \\
\text { ht }\end{array}$ & 5.1 & 2.185 & 1.690 & 0.179 & 0.146 & 0.476 & 0.193 & 0.045 & $\begin{array}{c}\text { Balan } \\
\text { ce }\end{array}$ \\
\hline
\end{tabular}

A schematic diagram of the stir-casting setup with different parts is shown in Figure 1.

At the beginning of the fabrication process, the aluminium rods were cut into small pieces and a graphite crucible of 6" in size was used for melting the pieces. Another crucible of 2" in size was used to preheat the reinforcement materials, i.e., $\mathrm{SiC}$ and $\mathrm{Al}_{2} \mathrm{O}_{3}$. The $\mathrm{Al} 7075$ alloy was also preheated at $400{ }^{\circ} \mathrm{C}$ for good blending. After preheating, the A17075 rods were put into the 6" crucible for melting and the temperature was increased gradually. At $650{ }^{\circ} \mathrm{C}$ the melting started and the process continued until the Al7075 became liquid at a temperature of $780{ }^{\circ} \mathrm{C}$.

The preheated reinforcements were now put into the casting furnace, run electrically, and mixed well with the base aluminium alloy using the stirrer available in the setup. To improve the wettability at the interface, $2 \mathrm{~g}$ of magnesium powder were added to the mixture. The stirrer can be operated by a motor at $480 \mathrm{~min}^{-1}$ to 500 $\mathrm{min}^{-1}$ for a period of $32 \mathrm{~s}$ in each spell. The molten

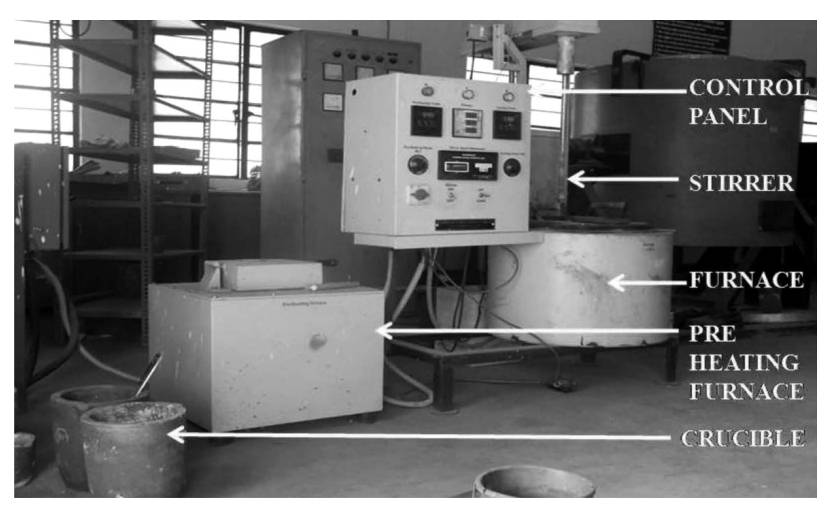

Figure 2: Experimental setup for stir casting 
materials were then poured into a square die of $100 \mathrm{~mm}$ $\times 100 \mathrm{~mm} \times 10 \mathrm{~mm}$ in size. The casting was removed from the mould after the solidification. Similarly, the castings of composites containing different weight percentages of reinforcement materials (3, 5, 7 and 9) w/\% of $\mathrm{SiC}$ with $2 \mathrm{w} / \%$ of $\mathrm{Al}_{2} \mathrm{O}_{3}$ in each composition were produced. The work was carried out at Karunya University, Coimbatore and the photograph of the stir-casting setup used is shown in Figure 2.

\subsubsection{Specimen preparation for tests}

The specimens used for the tensile tests were first machined in a milling machine and then cut into the required dimensions as per the ASTM E8M04 standard using a wire-cut EDM machine. The tensile tests were conducted using a Universal Testing Machine with a constant crosshead displacement rate for all the tests at $25{ }^{\circ} \mathrm{C}$. The mechanical characteristics of the samples, such as ultimate tensile strength (UTS), ductility (\% elongation) and $0.2 \%$ proof strength, were tested and the corresponding values obtained. The microhardness tests were conducted as per the ASTM B557M standard utilising an applied load of $0.49 \mathrm{~N}$ for a period of $15 \mathrm{~s}$.

To study the microstructure of the castings, test sections were cut from the castings, which were then belt grinded and polished with different grades of emery papers. Then the test pieces were again polished with cloths, washed and dried, after which they were etched with Keller's solution. The specimen thus prepared was then examined under a scanning electron microscope (SEM) and the micrographs were recorded for studying the microstructure. The broken specimens of the tensile tests were used to record the fractographs of the composite specimens with the SEM. The SEM micrographs clearly show the presence of clusters of $\mathrm{SiC}$ particulates in the fractured portions. During the application of the load, the cracks begin at these regions of hard clusters and then run into the ductile base alloy and to the ceramic regions that surround it.

\section{RESULTS AND DISCUSSION}

\subsection{SEM Microstructure studies}

The SEM micrograph images of the A17075-SiC$\mathrm{Al}_{2} \mathrm{O}_{3}$ composites of four different samples are shown in Figures 3a to 3d. It can be observed from the micrographs that the dispersion of reinforcement particles in the matrix material is almost uniform. It can thus be inferred that the stir-casting process has produced a composite with a homogenous mixture. The micrographs also clearly depict the presence of filler content in the composites. The whitish portions are silicon carbide, whereas the blackish portions are aluminium oxide particles. The micrograph of Figure 3a presents the composition of sample 1 containing Al7075 $+3 w / \%$ of $\mathrm{SiC}+$ $2 \mathrm{w} / \%$ of $\mathrm{Al}_{2} \mathrm{O}_{3}$. The figure shows the uniform distribution of $\mathrm{SiC}$ and $\mathrm{Al}_{2} \mathrm{O}_{3}$ ceramic particles in the aluminium alloy matrix with close-packed grains. The longish patterns could be due to solidification periods, the orientation of reinforcements into the matrix caused by the stirring process, the density and other factors that influence the settlement of the reinforcement particles into the matrix material. The micrograph of Figure $\mathbf{3 b}$ presents the composition of sample 2 containing Al7075 $+5 w / \%$ of $\mathrm{SiC}+2 w / \%$ of $\mathrm{Al}_{2} \mathrm{O}_{3}$. The dispersions of the $\mathrm{SiC}$ and $\mathrm{Al}_{2} \mathrm{O}_{3}$ particles are reasonably homogenous, while the formations of the grain patterns are comparatively larger. The formation of clusters of reinforcement particles can also be seen at some places in the micrograph. The characteristics of the composite at these places would give different results if the test area happens to coincide exactly with these places of the test specimen.

The micrograph of Figure $\mathbf{3 c}$ presents the composition of sample 3 containing $\mathrm{A} 17075+7 w / \%$ of $\mathrm{SiC}+2$ w/\% of $\mathrm{Al}_{2} \mathrm{O}_{3}$. The distribution of the $\mathrm{SiC}$ and $\mathrm{Al}_{2} \mathrm{O}_{3}$ particles in the aluminium alloy matrix is uniform, to some extent. The random grain orientation with clustering spots of ceramic particles could be due to an increase in the weight percentage of silicon carbide particles, which would influence the solidification pattern. The micrograph of Figure 3d presents the composition of sample 4 containing Al7075+9 w/\% of $\mathrm{SiC}+2 w / \%$ of $\mathrm{Al}_{2} \mathrm{O}_{3}$. Though the dispersion of reinforcement particles is nearly uniform, the presence of silicon carbide is more pronounced in the micrograph.

\subsection{Mechanical Properties}

Metal-matrix composite materials with the inclusion of ceramic reinforcements are fabricated to obtain favourable mechanical properties from the aggregate material. Different tests are carried out to quantify the increment or decrement caused by the reinforcements in
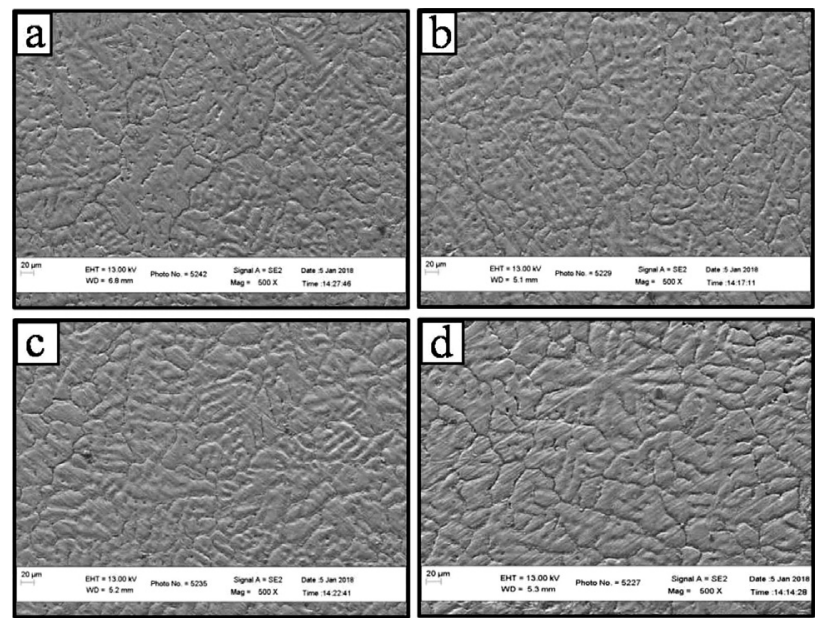

Figure 3: SEM micrographs of the composites with different compositions: a) $\mathrm{Al} 7075+3 w / \%$ of $\mathrm{SiC}+2 w / \%$ of $\mathrm{Al}_{2} \mathrm{O}_{3}$, b) $\mathrm{Al} 7075+$ $5 w / \%$ of $\mathrm{SiC}+2 w / \%$ of $\left.\mathrm{Al}_{2} \mathrm{O}_{3}, \mathrm{c}\right) \mathrm{Al} 7075+7 w / \%$ of $\mathrm{SiC}+2 w / \%$ of $\mathrm{Al}_{2} \mathrm{O}_{3}$, d) $\mathrm{Al} 7075+9 w / \%$ of $\mathrm{SiC}+2 w / \%$ of $\mathrm{Al}_{2} \mathrm{O}_{3}$ 


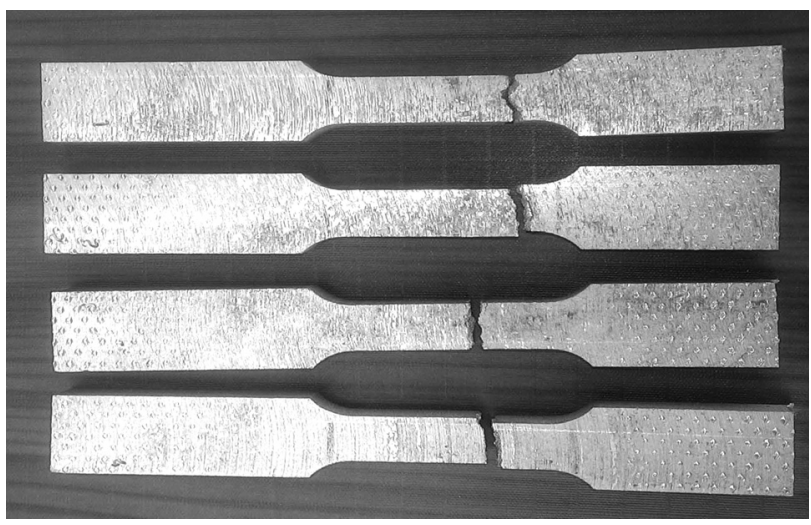

Figure 4: Photograph of tensile-tested fractured specimens

various properties of the base material. The tensile test specimens were prepared as per the ASTM standard ASTM E8M04 and specimens fractured under tensile test are shown in Figure 4.

To evaluate the mechanical properties of the newly formed composites, tensile test and Vickers microhardness tests were carried out. Table 2 gives the values obtained from the tests of the ultimate tensile strength, yield strength, percentage of elongation and microhardness for the four samples.

The analysis of the results clearly shows that the increment in the silicon carbide content has improved the ultimate tensile strength of the composite considerably.
The composition containing A17075+3 w/\% of $\mathrm{SiC}+2$ w/\% of $\mathrm{Al}_{2} \mathrm{O}_{3}$ has given a UTS value of $248 \mathrm{MPa}$, whereas the gradual increments of $\mathrm{SiC}$ in the composition have shown continuous improvements, with a UTS value of $325 \mathrm{MPa}$ for sample 4. The hard nature of the ceramic particles is the cause of the increment in strength. The improvement in the case of the yield strength also follows the same trend of continuous increment.

The results of the hardness tests of the four samples show a gradual improvement in the hardness values of the specimens, keeping in trend with the $2 \%$ weight increment of the $\mathrm{SiC}$ content in the samples. It is quite logical that the hard ceramic particles add to the hardness levels of the composite in proportion to the amount of their inclusion. Abdulhaqq et al. ${ }^{20}$ have analysed the significance of ceramic particles in increasing the hardness of the bulk of aluminium metal-matrix composites. The presence of the hard ceramic phase leads to a greater hardness of the composites than that of the base alloy. Vencl et al. ${ }^{21}$ have stated that the hardness of the composite improved significantly with the inclusion of an increased volume fraction of the ceramic particles.

The one mechanical property that shows a reduction for an increment of the weight percentage of ceramic particles in the composite is the strain to failure. It can be observed from the table that the percentage of elongation has decreased significantly from $3.44 \%$ (for sample 1)

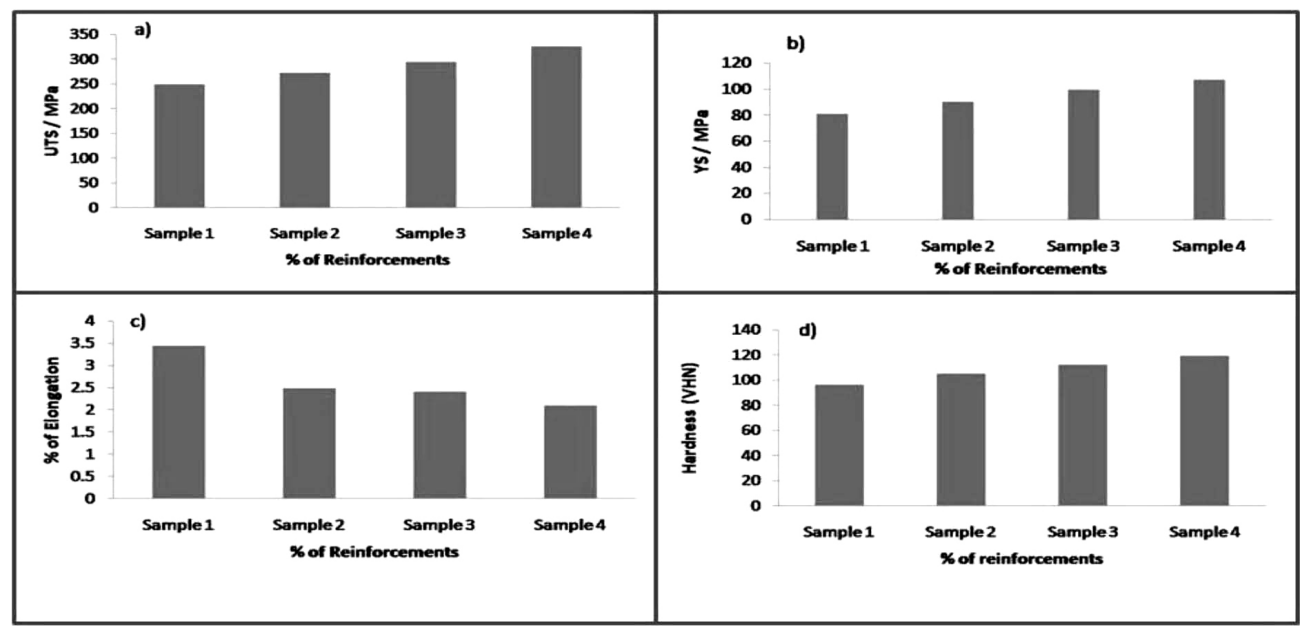

Figure 5: Mechanical properties of Al-MMC samples: a) UTS, b) YS, c) percentage of elongation, d) hardness

Table 2: Test results of mechanical properties for Al-MMC samples

\begin{tabular}{|c|c|c|c|c|}
\hline Sample identification & UTS (MPa) & YS (MPa) & $\begin{array}{l}\text { Percentage of } \\
\text { elongation }\end{array}$ & Hardness (VHN) \\
\hline $\begin{array}{c}\text { Sample no. } 1 \\
\left(\mathrm{Al} 7075+3 \% \mathrm{SiC}+2 \% \quad \mathrm{Al}_{2} \mathrm{O}_{3}\right)\end{array}$ & 248 & 81 & 3.44 & 96 \\
\hline $\begin{array}{c}\text { Sample no. } 2 \\
\left(\mathrm{Al} 7075+5 \% \mathrm{SiC}+2 \% \quad \mathrm{Al}_{2} \mathrm{O}_{3}\right)\end{array}$ & 272 & 90 & 2.48 & 105 \\
\hline $\begin{array}{c}\text { Sample no. } 3 \\
\left(\mathrm{~A} 17075+7 \% \mathrm{SiC}+2 \% \quad \mathrm{Al}_{2} \mathrm{O}_{3}\right)\end{array}$ & 294 & 99 & 2.40 & 112 \\
\hline $\begin{array}{c}\text { Sample no. } 4 \\
\left(\mathrm{Al} 7075+9 \% \mathrm{SiC}+2 \% \quad \mathrm{Al}_{2} \mathrm{O}_{3}\right)\end{array}$ & 325 & 107 & 2.08 & 119 \\
\hline
\end{tabular}


to $2.08 \%$ (for sample 4). The ceramic particles impart a brittle nature to the composite proportionate to the amount of inclusion and decrease the ductile nature, which could be attributed to the reduction in the elongation property. The values of ultimate tensile strength, yield strength, percentage of elongation and microhardness of the four samples tabled above are presented as graphs in Figure 5.

The effect of the inclusion of ceramic particles such as $\mathrm{SiC}$ and $\mathrm{Al}_{2} \mathrm{O}_{3}$ in the aluminium alloy composite on various mechanical properties is clearly depicted in the above figure. It is obvious from the figure that properties like the ultimate tensile strength, yield strength and hardness show improved values for all the samples, with the only exception being the percentage elongation, for which the values gradually decrease from sample 1 to sample 4 . The cause of this effect has been discussed in the above section.

\subsection{Fracture analysis}

Figures 6a to 6d show SEM fractographs of the Al7075-SiC- $\mathrm{Al}_{2} \mathrm{O}_{3}$ hybrid composites produced for experimental purposes. The broken tensile-test speci-
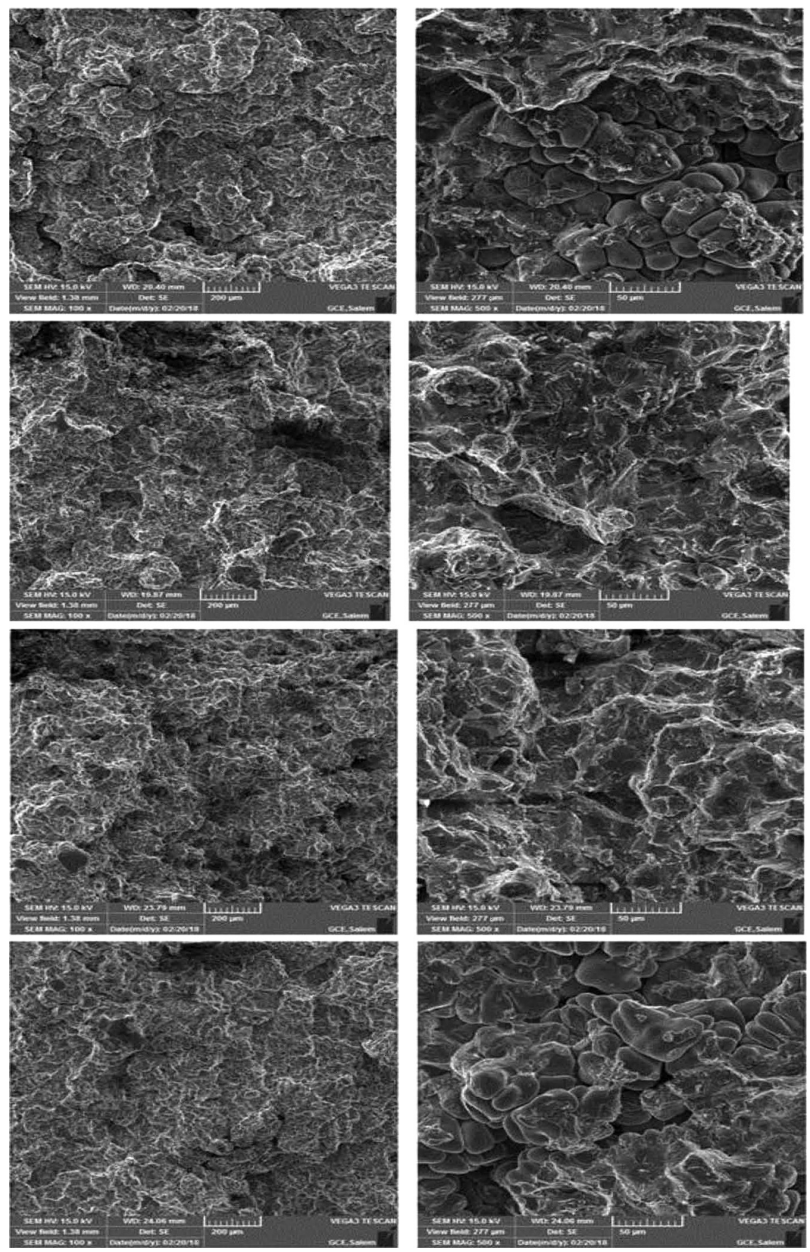

Figure 6: Fracture images of the composites with different compositions mens were used for the fracture analysis. The fracture is mainly of the transgranular type, which absorbs the maximum energy until the point of fracture, as the bulk of the material is ductile by nature. The initiation point of the cracks could be around the reinforcement particles, which grow progressively and coalesce into a bigger crack, weakening the spot with a void formation. Thus, the fractured portion shows both ductile and brittle modes of operation.

The mode of failure includes the decohesion of the $\mathrm{SiC}$ particles from the matrix at the interface. Dimples are formed around the silicon carbide particles due to the applied stress and the edges of these dimples are elongated, and the surface near the ceramic particle cracks around the interface. The crack even runs through these brittle particles. The clustering of ceramic particles provides an easy spot for a fracture to occur. Thus, from the images of the fractured samples, the presence of ceramic particles could be seen, which naturally become the most stressful part, prone to breakage, giving a brittle touch to the fracture, which otherwise would be mostly ductile.

\section{CONCLUSIONS}

The important conclusions inferred from the studies carried out on $\mathrm{SiC} \& \mathrm{Al}_{2} \mathrm{O}_{3}$ filled $\mathrm{Al} 7075$ alloy composites are as follows:

- Stir casting is an effective technique to produce hybrid metal-matrix composites with good miscibility.

- $\mathrm{SiC}$ and $\mathrm{Al}_{2} \mathrm{O}_{3}$ particles of 30/40 microns are added to the molten A17075 along with magnesium powder, which acts as a wetting agent for the uniform distribution of the reinforcements in the aluminium alloy matrix.

- The tensile strength and yield strength of the $\mathrm{SiC} \&$ $\mathrm{Al}_{2} \mathrm{O}_{3}$ filled $\mathrm{Al} 7075$ alloy composites were found to increase with an increase in the reinforcements.

- With the $w / \%$ increment in ceramic particles, the percentage elongation of the composite decreased.

- The hardnesses of the $\mathrm{SiC} \& \mathrm{Al}_{2} \mathrm{O}_{3}$ filled $\mathrm{A} 17075$ alloy composites were also found to increase with an increase in the amount of ceramic particulates added.

- The hard nature of the included ceramic particles improves the UTS, YS and hardness of the hybrid composite. The addition of ceramic particles imparts hardness and reduces the energy-absorbing capacity of the composite, causing a reduction in the percentage of elongation.

- The fractography studies show that the increase in the weight percentage of the $\mathrm{SiC} \& \mathrm{Al}_{2} \mathrm{O}_{3}$ changed the mode of failure from ductile to brittle, to some extent, which could be clearly observed from the dimples and deformed portions present near the regions of the fracture. 
- The microstructures clearly show the homogeneous distribution of the hard reinforcing particles in the matrix and the solidification pattern of the casting, which would influence the properties of the material.

- The SEM images clearly indicate the uniform distribution of the $\mathrm{SiC} \& \mathrm{Al}_{2} \mathrm{O}_{3}$ particles. The micrographs of the fractured portions indicate the presence of $\mathrm{SiC}$ particulates in clusters at some points, which initiate the fracture in the specimen and its hard nature provides a brittle mode to the otherwise ductile fracture.

\section{Acknowledgement}

The research work was supported by my mother Mrs. P. Dhanalakshmi and my spouse Mrs. A. M. Uma Maheswari. Special thanks to Professor Dr. K. K. Ramasamy and Dr. M. Premkumar from Paavai Engineering College, Namakkal, India, for their valuable help.

\section{REFERENCES}

${ }^{1}$ K. Komai, K. Minoshima, H. Ryoson, Tensile and fatigue fracture behavior and water-environment effects in a SiC-whisker/7075-aluminum composite, Composites Science and Technology, 46 (1993), 59-66

${ }^{2}$ A. N. Abdel-Azim, Y. Shash, S. F. Mostafa, A. Younan, Casting of 2024-A1 alloy reinforced with $\mathrm{A}_{2} \mathrm{O}_{3}$ particles, Journal of Materials Processing Technology, 55 (1995), 199-205

${ }^{3}$ K. B. Lee, H. Kwon, Strength of Al-Zn-Mg-Cu matrix composite reinforced with $\mathrm{SiC}$ particles, Metallurgical And Materials Transactions A, 33a (2002), 455-465

${ }^{4}$ S.-J. Hong, H.-M. Kim, D. Huh, C. Suryanarayana, B. S. Chun, Effect of clustering on the mechanical properties of $\mathrm{SiC}$ particulate reinforced aluminum alloy 2024 metal matrix composites, Materials Science and Engineering, A347, (2003), 198-204

${ }^{5}$ Ali Kalkanli, Sencer Yilmaz, Synthesis and characterization of aluminum alloy 7075 reinforced with silicon carbide particulates, Materials and Design, 29 (2008), 775-780, doi:10.1016/j.matdes. 2007.01.007

${ }^{6}$ S. A. Sajjadi, H. R. Ezatpour, H. Beygi, Microstructure and mechanical properties of $\mathrm{Al}-\mathrm{Al}_{2} \mathrm{O}_{3}$ micro and nano composites fabricated by stir casting, Materials Science and Engineering A, 528 (2011), 8765-8771, doi:10.1016/j.msea.2011.08.052

${ }^{7}$ Daljeet Singh, Harmanjit Singh, Som Kumar, Gurvishal Singh, An experimental investigation of mechanical behavior of aluminum by adding SiC and alumina, International Journal on Emerging Technologies, 3 (2012) 1, 178-184

${ }^{8}$ Indumati B. Deshmanya, Dr. Purohit, GK, Chemistry and material research, modelling tensile behaviour of stir-cast aluminium matrix composites (AMCs) using factorial design of experiments, Chemistry and Material Research, 2, (2012) 1, 129-142
${ }^{9}$ V.C. Uvaraja, N. Natarajan, Optimization of friction and wear behaviour in hybrid metal matrix composites using taguchi technique, Journal of minarals and materials characterization and engineering, 11 (2012), 757-768

${ }^{10}$ R. K. Bhushan, S. Kumar, S. Das, Fabrication and characterization of $7075 \mathrm{Al}$ alloy reinforced with $\mathrm{SiC}$ particulates. The International Journal of Advanced Manufacturing Technology, 65 (2013) 5-8, 611-624, doi:10.1007/s00170-012-4200-6

${ }^{11}$ S. Baskaran, V. Anandakrishnan, Muthukannan Duraiselvam, Investigations on dry sliding wear behavior of in situ casted AA7075-TiC metal matrix composites by using Taguchi technique, Materials and Design, 60 (2014), 184-192, doi:10.1016/j.matdes.2014.03.074

${ }^{12}$ C. D. Wu, P. Fang, G. Q. Luo, F. Chen, Q. Shen, L. M. Zhang, E. J. Lavernia, Effect of plasma activated sintering parameters on microstructure and mechanical properties of Al-7075/B4C composites, Journal of Alloys and Compounds, 615 (2014), 276-282, doi:10.1016/j.jallcom.2014.06.110

${ }^{13}$ Vignesh. V. Shanbhag, Nitin. N. Yalamoori, S. Karthikeyan, R. Ramanujam, K. Venkatesan, Procedia engineering fabrication, surface morphology and corrosion investigation of $\mathrm{Al} 7075-\mathrm{Al}_{2} \mathrm{O}_{3}$ matrix composite in sea water and industrial environment, Procedia Engineering, 97 (2014), 607-613, doi:10.1016/j.proeng.2014. 12.289

${ }^{14}$ B. Rajeswari, K. S. Amirthagadeswaran, K. Anbarasu, Investigation on mechanical properties of aluminium 7075-Silicon carbidealumina hybrid composites using taguchi method, Australian journal of mechanical engineering, 13 (2015), 127-135, doi:10.7158/M13051.2015.13.2

${ }^{15}$ T. A. Md, A. Ansari, S. Arif, Md. N. Alam, Mechanical properties and morphology of aluminium metal matrix nanocomposites - stir cast products, adavances in materials and processing technologies, (2017) 1-15, doi:10.1080/2374068X. 2017.1350543

${ }^{16}$ N. Ashok, P. Shanmughsundaram, Effect of particles size on the mechanical propeties of $\mathrm{SiC}$ - Reinforcement aluminium 8011 composites, Mater. Tehnol., 51 (2017) 4, 667-672, doi:10.17222/ mit.2016.252

${ }^{17}$ M. Sambathkumar, P. Navaneethakrishnan, K. Ponappa, KSK. Sasikumar, Mechanical and corrosion behaviour of A7075 (hybrid) metal matrix composites by two step stir casting process, Latin american journal of solids and structures, 14 (2017), 243-255, doi:10.1590/1679-78253132

${ }^{18}$ S. T. Mavhungu, E. T. Akinlabi, M. A. Onitiri, F. M. Varachia, Aluminium matrix composites for industrial use: Advances and trends, Sciencedirect Procedia manufacturing, 7 (2017), 178-182, doi:10.1016/j.promfg.2016.12.045

${ }^{19}$ C. Kannan, R. Ramanujam, Comparative study on the mechanical and microstructural characterisation of AA7075 nano and hybrid nanocomposites produced by stir and queeze casting, Journal of Advanced Research, 8 (2017), 309-319, doi:10.1016/j.jare.2017. 02.005

${ }^{20}$ Abdulhaqq A. Hamid, P.K. Ghosh, S.C. Jain, Subrata Ray, The influence of porosity and particles content on dry sliding wear of cast in situ $\mathrm{Al}(\mathrm{Ti})-\mathrm{Al}_{2} \mathrm{O}_{3}(\mathrm{TiO} 2)$ composite, Wear 265, 1-2, (2008) 25 , 4-26, doi:10.1016/j.wear.2007.08.018

${ }^{21}$ A. Vencl, I. Bobi, Z. Mi; skovi, Effect of thixocasting and heat treatment on the tribological properties of hypoeutectic Al-Si alloy, Wear 264, (2008), 616-623, doi:10.1016/j.wear.2007.05.011 